\title{
STRUCTURAL CHANGES OF THE MALAYSIAN ECONOMY AND ITS SPATIAL INCIDENCE ON REGIONAL ECONOMIC GROWTH
}

\author{
Mohammad Abdul Mohit ${ }^{1}$ \\ Kulliyyah of Architecture and Environmental Design \\ INTERNATIONAL ISLAMIC UNIVERSITY OF MALAYSIA
}

\begin{abstract}
The economy of Malaysia has undergone changes from its agricultural base to importsubstitution during the 1960s and finally to export-orientation after 1968, associated with an influx of significant amount of direct foreign investment (DFI). These changes of the production base of the country led to concomitant changes in the structure of employment from agriculture to manufacturing and finally to services. Studies so far undertaken mostly concentrate on the macro aspect of this transformation process. No attempt has been made to study the structural changes of the national economy through analyzing the production/ employment structure of the regions/states of Malaysia. In spit of adopting and implementing a number regional development policies and strategies from 2MP, it is anticipated that the structural transformation has not been uniform across the different regions of the country. Therefore, this paper provides a spatial analysis of the structural changes in the structure of production and employment that has occurred across fourteen states of Malaysia. The study found that the economic growth process has been unequal across the 14 states of Malaysia, accentuating the regional disparities in income and employment growth. Both federal government development expenditure and private investments in different states of Malaysia have not been proportionate to their shares of national population and this partially explains the reason for the interregional differences of economic growth in the country.
\end{abstract}

Keywords: Structural Transformation, Import Substitution, Export orientation, Direct Foreign Investment (DFI), Gross Domestic Product (GDP), Theil Index, Free Trade Zone (FTZ)

Department of Urban \& Regional Planning, Kulliyyah of Architecture \& Environmental Design, International Islamic University, Malaysia.

(Email: mamohit@iiu.edu.my) 


\section{INTRODUCTION}

The economic structure of Malaysia has undergone dramatic changes since Independence in 1957 . The production base of the economy was broadened from the processing of primary commodities (particularly rubber), small scale food industries and handicrafts during the early 1960 s to manufacturing (import-substitution) which accounted for a growing share of national output and employment. However, the need to extend industrialization upstream, especially the manufacturing of intermediate goods, was stressed in the First Malaysia Plan 1966-70.

A radical shift from an inward-looking, defensive industrialization strategy of import substitution to an outward-looking, aggressive strategy of export promotion took place after 1968 when it became obvious that import substitution could no longer provide a viable basis for sustained industrial expansion, given the small domestic market. Indeed, both export orientation and import substitution were pursued in a somewhat parallel fashion although stronger emphasis was placed on the former. Accordingly, investment incentives were restructured so as to offer a variety of export incentives under the Investment Incentives Act 1968, including export allowances and accelerated depreciation, tax holidays, investment tax credit and other fiscal incentives were aimed at export-oriented industries. Pre-shipment and postshipment export credit refinancing facilities were also introduced. At the physical infrastructural level, 12 Free Trade Zones (FTZs) were established where nearly three-quarters of the firms were foreign-owned and they accounted for more than $90 \%$ of the total direct employment within the FTZs.

The changing structure of the Malaysian economy is reflected in the changing composition of the country's gross domestic product (GDP). Fig.1 shows that the share of the agricultural sector in the GDP has declined from 30.8 per cent in 1970 to 8.2 per cent in 2005 , while that of manufacturing sector has grown rapidly from 13.4 percent to 31.4 over the same period. ${ }^{i}$

Structural changes in the Malaysian economy have also been reflected in the changing pattern of sectoral employment as presented in Fig.2 where it can be seen that there is a rising proportion of the labour force in the manufacturing sector, while the share of government services in total employment declined from 1985 onwards due mainly to the privatization of some public sector activities in the country.

Studies so far undertaken mostly concentrate on the macro-economic aspect of this transformation process (Onn, 1986; Ariff, 1991). A few studies 
have attempted to analyze the phenomena through industrial concentration (Aiken, et al. 1982). Okposin et.al., (1999) did a comprehensive study on the changing phases of the Malaysian economy covering macroeconomic policies, framework and management, industrialization policies and strategies, agricultural and tourism development, financial sector and privatization, manpower and environmental development, including Vision 2020 and Multimedia Super Corridor development.

Tan and Ariff (2001) reviewed the industrial structure and policies of Malaysia from late 1960s until up to 1990s. Salih, et al., (2000) documented the dramatic changes of the Malaysian economy over the past three decades (1960 to 1990) and examined the long term outlook of the Malaysian in the context of post-1990 external and domestic environment. The various five-year Malaysia Plans provide data and analysis on the inter-state distribution of GDP, per capita GDP, unemployment rate and employment by sectors. Nevertheless, a few fragmentary attempts have been made to study the spatial incidence of the structural changes of GDP through changes in the production/ employment structure of the regions / states of Malaysia. Ghaffar (1987) identified three causes of regional disparities; first, the impact relief, climate and distribution of natural resources; second, the impact of colonial rule on the social, economic and spatial structure; and third, insufficient attention to the spatial aspects of resource allocation. Although it has been admitted that the problems of regional inequalities in development and poverty are the major issues of the country (Salleh, 2000, p.5), systematic studies highlighting the relationships between national and regional economic growth through production and employment changes are lacking and hence, the present paper intends to fill in the gap. It is anticipated that the structural transformation of the national economy has not been uniform across the different regions ${ }^{i j}$ of the country. Hence, from welfare perspective, there is a need to study the spatial matrix of the structural transformation through the changing structure of production and employment of the regional economies of Malaysia. 


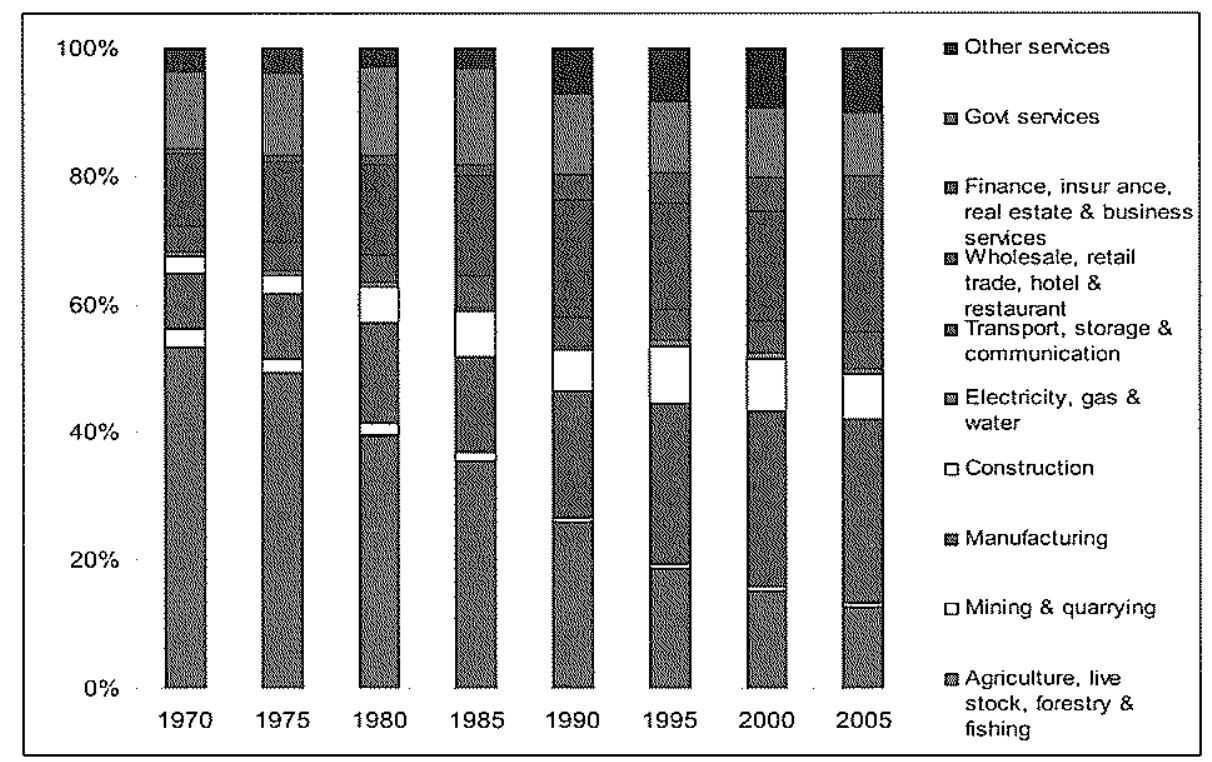

Figure 1: Changes in the Composition of GDP of Malaysia during 1970-2005. (Sources: Compiled from Various Five-Year Plans of Malaysia.)

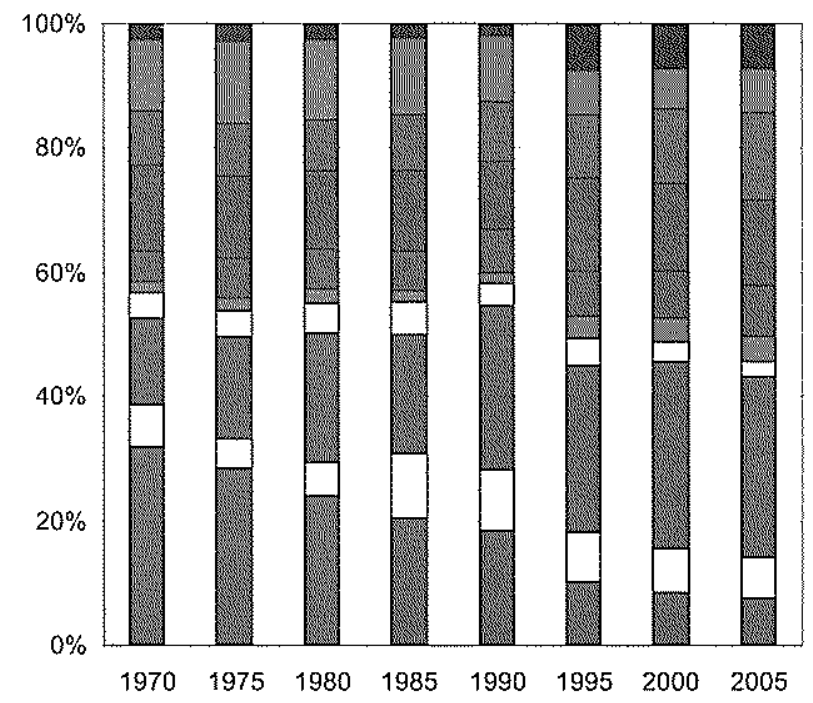

E Other services
a Gov senices
m Finance, insurance, real
estate \& business services
w Wholesale \& retail trade
Transport, storage \&
communication
Electricity, gas \& water
C Construction
a Manufacturing
Mining \& quarrying
agriculture, livestock,
forestry \& fishing

Figure 2: Changes in Employment Structure of Malaysia during 19702005. (Sources: Compiled from Various Five-Year Plans of Malaysia.) 


\section{LITERATURE REVIEW}

The spatial impress of economic development has always been uneven and hence regions grow at different levels within the national development process. Despite a good deal of research by economists, economic historians and economic geographers, there is still no generally accepted explanation as to why regional differences of growth occur. Although there is no single integrated theory that can explain the regional development process, there are a number of theories and concepts that can provide explanations to the regional growth process (Choguill, 1979). Three theories - neoclassical growth model, exportbase approach and cumulative causation model, partially explain the phenomena. The neoclassical models stress supply-side influences on growth; export base approach stresses the importance of the demand for regional exports in the growth process and cumulative causation models stress the selfperpetuating nature of the growth process. Recently, attempts have been made to incorporate the principle of self-perpetuation into all growth theories, including new growth theory based upon endogenous growth. But these models are still in their infancy and require further development if they are to prove successful in explaining regional growth disparities and in identifying the major determinants of growth. Regional growth theory still has a long way to go and therefore a long future lies ahead of it (Armstrong and Taylor, 2004, p.117-8).

The theoretical perspective of the regional growth process, particularly based on the cumulative causation model (Myrdal, 1957) and Hirschman's (1958) theory, can be conceptualised into the divergence-convergence formulation which states that in the early stages of development, the developed centres enjoy the existence of external economies and other urbanising forces which lead to polarization and divergence of regional per capita incomes. However, at a later stage of growth, a process of convergence starts through the spread or trickle down of growth impulses to other areas and eventually, this will lead to a decrease of the regional income disparities. This process has been designated as $\beta$-convergence ${ }^{\mathrm{iii}}$ and $\sigma$-convergence ${ }^{\mathrm{iv}}$ (Armstrong and Taylor, 2004, p.82).

Empirical evidences on the validity of divergence-convergence syndrome are numerous. Williamson (1965), based on cross-sectional data of 24 countries, found that nations with intermediate levels of per capita income exhibit the largest regional inequalities than the highly developed and least developed nations. Based on time series data of 10 countries, he observed that increasing inequalities is associated with the early stages, while decreasing inequality is associated with mature stage of development. Empirical studies by Mera (1973; 1978) and later by Tabuchi (1988) seem to support the above findings, while 
others like Gilbert and Goodman (1976) are critical of Williamson's findings. According to them, regional disparities are unlikely to diminish unless national governments adopt strong regional development programmes. Their view is shared by Hansen (1981) and Nicols (1969). Ficsh (1984) calculated a dissimilarity index of US income for the years 1950, 1960 and 1970, as a measure of regional inequality and found that there was no clear empirical pattern emerging from his research. Barro and Sala-i-Martin (1995) examined the growth rates across the US states from 1880 to 1988 and found evidence of convergence of roughly $2 \%$ per year. Armstrong (1995) finds a similarly slow rate of convergence across regions of the EU. International studies of convergence by Sala-i-Martin (1996) indicate that regional convergence of per capita incomes has generally been slow in industrialised countries. Lall and Yilmaz (2001) examined the convergence across US states covering 1969-95 period when there were transformation of the economy from manufacturing to service base in the early 1980 s and found that the concentration of those activities in a few states negatively affected the convergence tendencies.

According to Armstrong and Taylor (2002), "there is evidence that slow convergence of regional per capita incomes also appears to have occurred within individual EU member states as well as within many other countries around the world such as Japan, Canada, Australia and India". Similarly, Terrasi (2000) found a converging trend of regional per capita income and other variables, while she was comparing regional per capita income convergence of Italy and Spain on a comparative plane. On the contrary, Gezici and Hewings (2004) found little evidence of convergence of GDP growth per capita across the provinces and functional regions of Turkey during 1980-97.

Several regional development strategies and policies such as growth centre, urbanization, industrial dispersal, in situ development, resource frontier development, growth triangle development, have been adopted and implemented in Malaysia. "However, the outcome of those policies has not been very encouraging. It has been remarked that despite a strong state intervention in the planning and implementation of regional development programmes, the performance had been unsatisfactory (Mohd Yusof Kasem, 1992, p.55), and the impact of the government's efforts in reducing the growing regional disparities is marginal (Salleh, 2000, p.56). Even, the regional growth objectives and strategies adopted in various five year plans to enhance economic growth of lagging regions as well as decentralize the concentration of production and some commercial activities from core regions, have proved to be elusive (Hamzah Jusoh, 1992, p.22). 
From the theoretical perspective and empirical studies, it appears that the divergence-convergence issue of regional growth is still open for further research both nationally and internationally. The present paper intends to fill in the gap of research that currently exist in Malaysia, where spatial incidence of structural changes of the national economy has led to the growth of imbalances in regional economic development in the country.

\section{OBJECTIVES AND METHODOLOGY}

The aim of the paper is to analyze the spatial incidence/connotation of the structural changes of the Malaysian economy from the regional perspective and as such the following objectives have been set:

a) Investigate the pattern of economic growth of Malaysia through employment and production changes;

b) Analyze the regional/state economic development through income and employment changes;

c) Identify and analyse the regional imbalances/disparities following from the national development process; and

d) Suggest policy directions to reduce regional imbalances of development.

The general hypothesis tested in the study is based on the fact that the regional growth resulting from or commensurate to the structural transformation of the Malaysian economy has not been uniform across the fourteen states of the country as can be observed from Figure 3 which shows state-wise variations of monthly household incomes in 2005.

\section{Data source}

The paper is based on secondary data. Data/information published by government, semi-government and private agencies were intensively utilized for deriving conclusions for the study. Four main sources were used to collect data/ information the following:

a) Data/information contained in the various five-year national development plans;

b) Statistical data/reports published by the Department of Statistics Malaysia.

c) Books, articles, conference proceedings.

d) Unpublished materials like dissertations and theses. 


\section{Data Analysis}

Simple statistical techniques such as charts, tables, were used to make the data meaningful and derive conclusions from thereon. XCEL, SPSS PC+ Software were used for data analysis. Mapinfo GIS was used to make the analysis spatially focused and meaningful.

\section{Analysis Techniques}

Four analysis tools were adopted for the study. These are narrated as follows:

\section{Theil Index}

Theil (1967) coefficient of concentration which is apt for comparing inequalities of different regional systems was applied in the study. The index is calculated by using the following formula:

$$
I C=\Sigma Y i \log (Y i / X i)
$$

Where $I C$ is the Theil index, $Y i$ is the share of GDP for region $i$ and $X i$ is the share of national population for the same region. The index is standardized by dividing the equation by its maximum value, which is $\log (P)$, where $P$ is the national population (Walsh and O'Kelly, 1979). The value of the index of regional inequality ranges between zero (0), corresponding to perfect equality and one (1) corresponding to maximum inequality. Theil index has been used by many authors (Terrasi, 2000; Gezici and Hewings, 2002) in regional studies.

\section{Per Capita Regional GDP}

From economic welfare perspective, output per capita is considered an important variable. Hence, regional disparities in GDP per capita have figured strongly in defining regions in need of special assistance through the EU's Structural Funds. The increasing interest of policy makers in regional disparities in output per capita has been one of the primary motivating forces behind the recent spur of empirical studies which attempt to explain these disparities (Armstrong and Taylor, 2004, p.88).

\section{Shift-Share Analysis (SSA)}

Shift-share analysis (SSA) is a technique which provides some insights into the pattern of regional employment changes. The analysis divides the growth of regional employment over a period of time into three constituent parts; (1) the 
part that is due to the region's share in national growth, that is, if the national economy is growing the region should experience growth; (2) the part that is due to the region's specific mix of industry, that is, if the region has above average representation of growth industries it should benefit accordingly; and (3) the part that is due to residual influences not included above, that is, regional growth not explained by industrial structure. SSA would therefore predict that a region with a favourable mix of industry would experience higher employment growth than a region with an unfavourable mix of industry. The formula used for calculating the shift-share components for a single sector/ industry is expressed as follows:

Share Component: $\mathrm{SH}=e_{i}\left[\left(N^{*} / N\right)-1\right]$.

Mix Component: MIX $=e_{i}\left[\left(N_{i}^{*} / N_{i}\right)-\left(N^{*}-N\right)\right]$.

Competitive Component: $\mathrm{COM}=e_{i}\left[\left(e_{i}^{*} / e_{i}\right)-\left(N_{i}^{*} / N_{i}\right)\right]$.

Where:

$e_{i}=$ local employment in sector/industry ${ }_{i}$ at the beginning of the period.

$e_{i}^{*}=$ local employment in sector/industry ${ }_{i}$ at the end of the period.

$N^{*}=$ total national employment at the end of the period.

$N=$ total national employment at the beginning of the period.

$i=$ indicates reference to industry/sector.

Despite being criticised as an approach that is easy to use and understand, the analysis has been widely used by planners and economic development officials to help them understand the economic performance of regions (Blair, 1991, p.190).

\section{Federal Government Development Expenditure and Private Sector Investment}

Federal Government development expenditure in the form of infrastructural grants can impact the regional growth process through providing attractions to the investors. Similarly, the private sector's industrial investment in different states or regions can increase the regions' ability to generate employment and income in their territories. Gezici and Hewings (2002) and Hamzah Jusoh (1992) have used this technique in regional analysis.

\section{NATIONAL ECONOMIC GROWTH AND REGIONAL DISPARITIES}

In the last four decades, Malaysia has made striking progress in economic development when measured by using such criteria as growth rates, stability of 
internal prices, and balance of payment strengths. However, development conceived in these terms is a value laden fraud which means that while gross indicators portray a bright picture, there may be an extreme distribution of development in spatial and human terms (Aiken, S.R. et. al., 1982, p.92).

In order to unravel the regional disparities of development among the fourteen (14) states of Malaysia (Figure 3), the Theil coefficient of concentration has been presented in Figure 4 with the real per capita GDP growth rate of the country during 1970-2005. Both real Per Capita GDP ${ }^{\text {vi }}$ and the Theil index of regional disparity have increased concurrently with a rank (rho) correlation coefficient of 0.90 significant at 0.001 level ${ }^{\mathrm{vii}}$. However, the annual growth rate of per capita real GDP was 5.8 percent compared to the disparity indices which grew at a rate of 1.5 per cent during the same period.

\section{NATIONAL ECONOMIC AND REGIONAL PER CAPITA GDP GROWTH}

Malaysia's spectacular economic performance has led to an increase of the per capita real GDP from RM ${ }^{\text {vii }} 1,939$ in 1970 to RM 13,546 in 2005. However, the increase in the per capita income has not been uniform across the 14 states of the country.

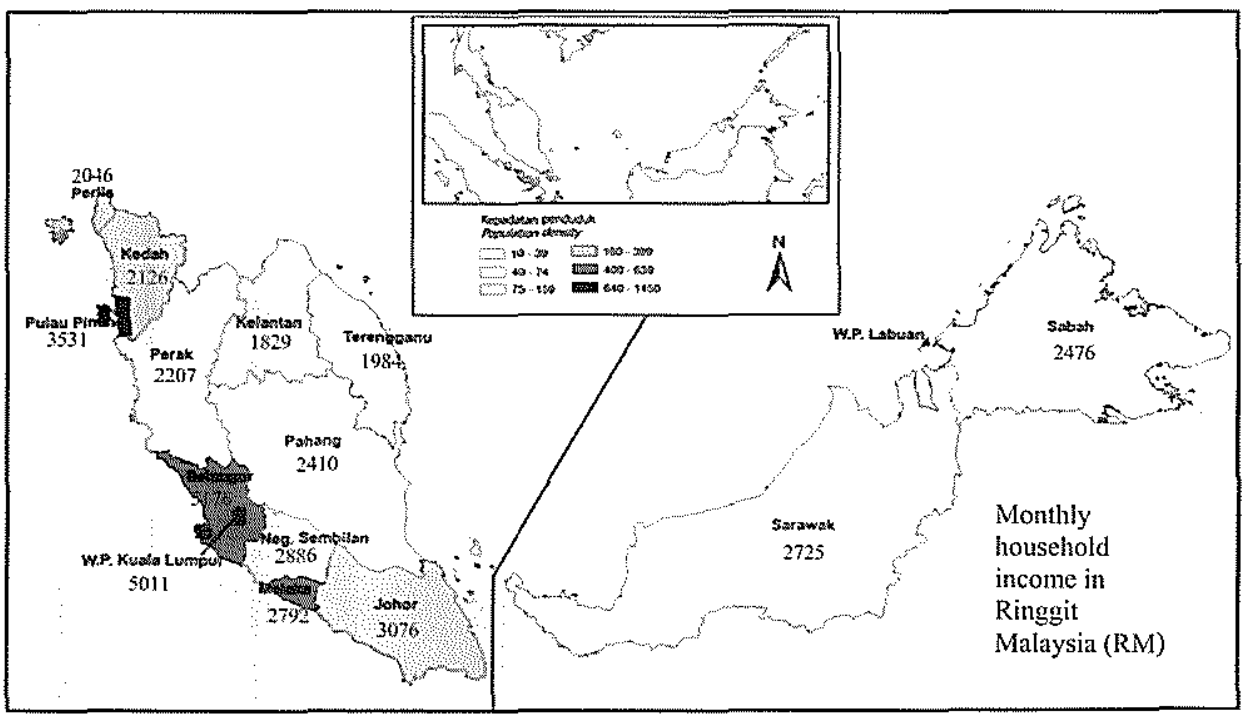

Figure3: Population Densities and Household Monthly Incomes by States of Malaysia

(Source: Dept. of Statistics Malaysia, 2005) 


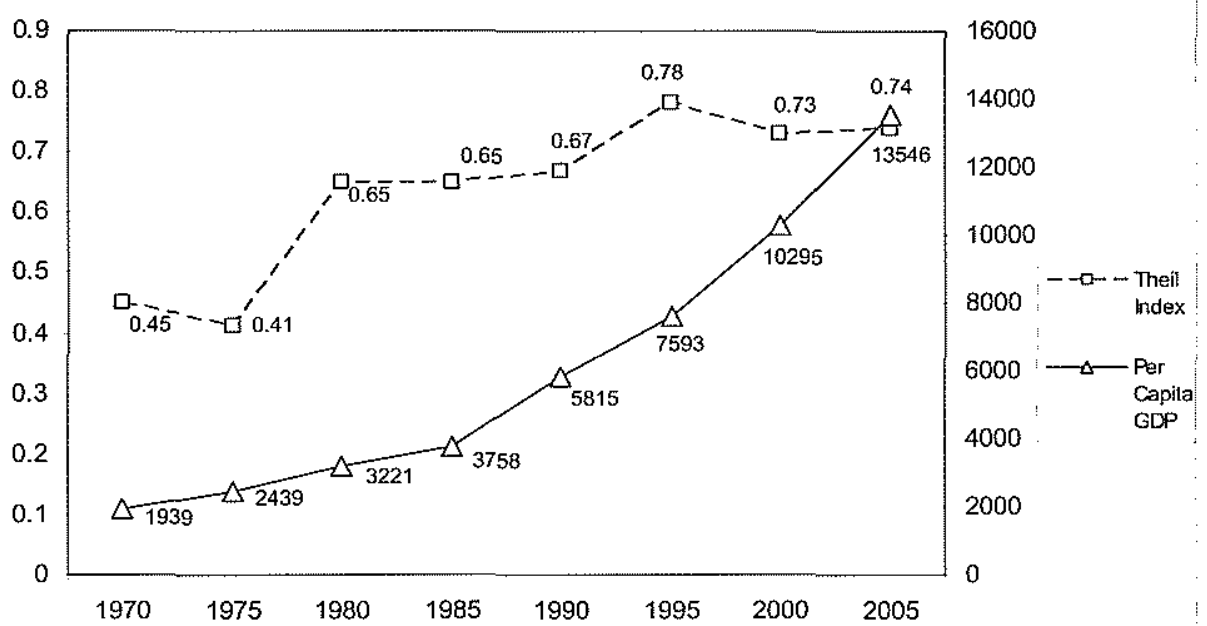

Figure 4: Theil Index and Real per capita GDP Growth of Malaysia during 1970-2005.

(Source: Author's Calculations based on data from various Five-Year Plans of Malaysia)

The Third Malaysia Plan (1971) stated that "as a result of historical patterns of development, the different states and regions of Malaysia have shown very different rates of development, resulting in very unequal distribution of income, amenities and opportunities. Not only does output growth vary greatly between regions; there are also substantial regional variations in the growth of output per capita as well" ( $3^{\text {rd }}$ Malaysia Plan, 1971, p.210). Even the National Physical Plan (2005) has admitted that in Peninsular Malaysia, imbalances in economic growth exist between the West and East Coasts, within the West Coast, imbalances also occur between the more developed states such as Pulau Pinang and Perak with the northern states like Kedah and Perlis - reducing these imbalances is important towards enabling Malaysia to achieve national integration (JPBD, 2005, p.5-6). To investigate the spatial impress of the national growth process, per capita regional GDP of 14 states have been calculated with national per capita GDP (as a base of 1.00) for a period of 35 years beginning from 1970 to 2005. In Figure 5, the figure shows that there have been northern-southern, central-eastern differences in the growth of regional per capita income in Malaysia. ${ }^{i x}$ The northern region comprises of four states of the country - Perlis, Kedah, Pulau Pinang and Perak; 3 (75\%) of the states had per capita income less than the national average over the 35 -year period. The central region comprising of three states - Selangor, Negeri Sembilan, Melaka and the federal territory of Kuala Lumpur; 3 states or $75 \%$ of the region had maintained their per capita GDP growth above the national 
average during the same period. The eastern region has three states - Kelantan, Terengganu and Pahang, only one state $(33.3 \%)$ had per capita GDP above the national average. The southern region - the state of Johor, and east Malaysia region of the states of Sabah and Sarawak, have their per capita income below the national average.

Nine states $(64 \%)$ of Malaysia, out of 14 , were low achievers in terms of per capita income, of which two states - Sabah and Negeri Sembilan have experienced continual declines in their per capita GDP. Five states $(36 \%)$ of Malaysia are high achievers of per capita GDP, of which three states - Pulau Pinang, Terengganu and Melaka have shown increasing trend in their per capita GDP achievements. Among the high per capita GDP achieving states, FT Kuala Lumpur has the highest achievement followed by Terengganu, Pulau Pinang and Selangor. Three states - Kelantan, Kedah and Perlis, have continually remained low achievers of per capita GDP over three and a half decades. The per capita GDP gap between lowest and highest achieving states - FT Kuala Lumpur and Kelantan, declined marginally in 1980 and then onwards it started increasing and from 1985 the gap almost remained parallel.

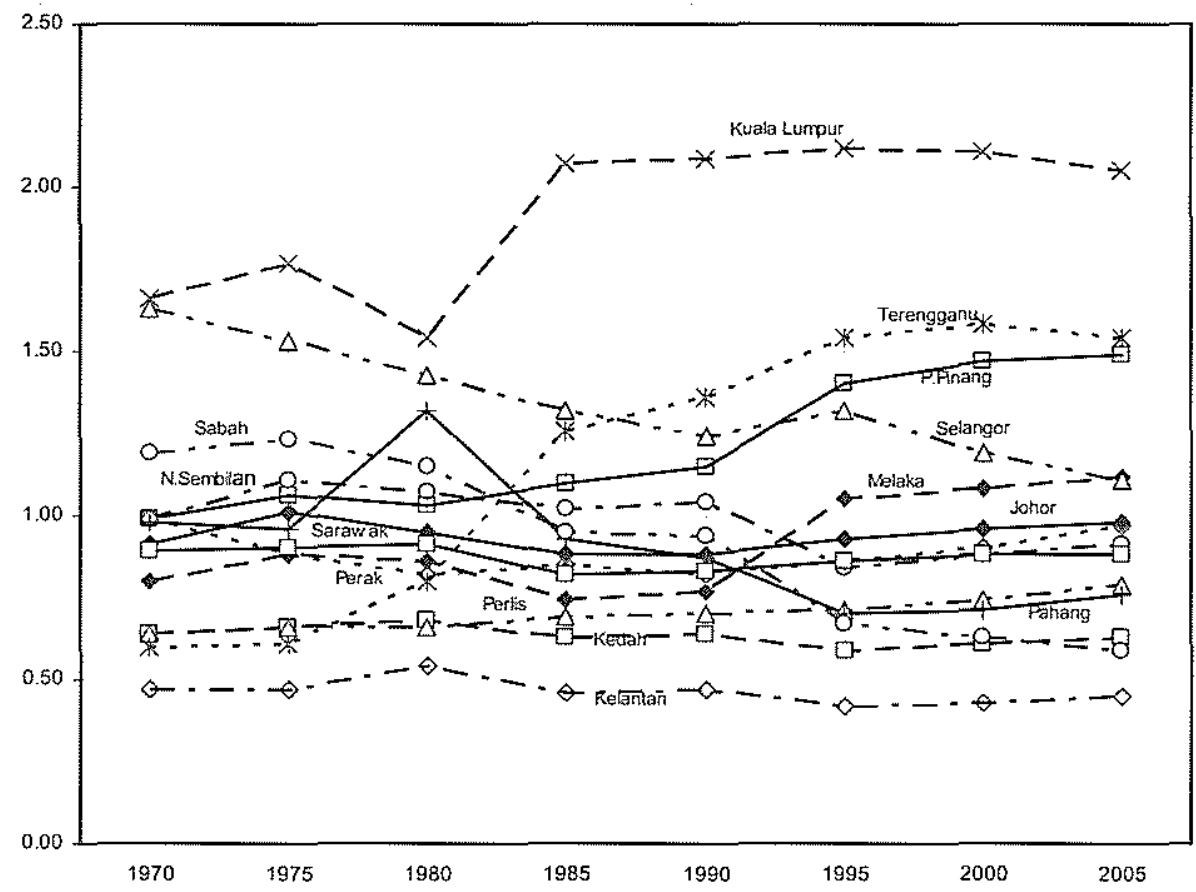

Figure 5: Distribution of Per Capita State GDP to National GDP Ratios during $1970-2005$.

(Sources: Author's Calculations Based on Data from various Five-Year Plans of Malaysia) 


\section{REGIONAL EMPLOYMENT GROWTH AND CHANGES}

The overall growth rate of a region's activity as measured by total employment is a weighted average of the growth rates of the separate sectors or activities making up the region's economy. If a region's growth rate is compared with that of another region, it is possible to explain the difference of growth rates statistically in terms of two components - mix and competitive. Quantitative analysis of comparative regional growth rates can be done by using the "Shiftshare" approach. If a region contains mainly fast-growing activities and relatively few slow-growing activities, it can be said to have a favourable growth mix of activities and its overall percentage growth rate will exceed the nation. On the other hand, if slow-growing industries are more than proportionally represented in the region's mix, the region's overall growth rate will be slower than the national growth rate. If a region has same mix of activities as does the nation, and its percentage share of the national total is the same for all activities, the region will have an overall growth rate higher than that of the nation if it increases its shares (that is, if most activities grow faster in the region than in the nation). Such a case represents the competitive component in isolation. In any real situation, it is nearly certain that the relative growth rates of the region and nation will show the effects of some combination of mix \& competitive components. The effect and the net result can be either positive or negative.

In order to explain the comparative regional growth process of Malaysia, regional employment data of 22 years starting from 1982 to 2004 were analysed by using share-shift technique. The result of the analysis presented in Table-1 shows that three states $(21.5 \%)$ - Johor, Pulau Pinang, and Selangor, out of 14 , had experienced employment growth above the national rate and they achieved positive shares and positive mix and competitive shifts. Among the three, Selangor followed by Pulau Pinang, and Johor had achieved a favourable economic environment in which regional activities and employment have been positive. Eight states (57\%) - Kelantan, Melaka, Negeri Sembilan, Pahang, Perak, KL, Terengganu, and Perlis, had a positive mix but a negative competitive component, which stand to indicate that these regions had a favourable growth mix compared to the nation. But the existence of a negative competitive shift indicates that these regions lost out to that extent in competitive position vis-à-vis the rest of the country. Three states - Sabah, Sarawak and Kedah experienced a negative mix with negative competitive components, except for Sabah, which indicates that the industries of these states are of types that are less competitive nationally. Table-1 also shows the incidence of poverty and unemployment rates by the states of Malaysia. We did a correlation analysis and found that the coefficient is significant with the MIX 
component only stands to suggest that both unemployment and incidence of poverty can be reduced by enhancing the mix component of regional employment.

The aggregate share-shift components need to be decomposed by sectors to get a better understanding of the regional economies. Three broad sectors have been considered - agriculture, industry and services. ${ }^{x}$ Table-2 presents sector specific shift-share analysis of state economies. The table shows that the agriculture sector has achieved negative regional growth, mix and competitive components almost in all the states except Sabah where the regional employment has been higher than the national share and the competitive component is positive, which indicates the competitiveness of local industries of agriculture sector vis-à-vis the national sector.

Table 1: Shift- Share Analysis of Regional Employment Changes in Malaysia, 1982-2004 (in 000s)

\begin{tabular}{|c|c|c|c|c|c|c|}
\hline \multirow[t]{3}{*}{ State/ Region } & \multirow{3}{*}{$\begin{array}{l}\text { Regional } \\
\text { Employment } \\
\text { Growth }\end{array}$} & \multicolumn{3}{|c|}{ Components } & \multirow{3}{*}{$\begin{array}{l}\text { Incidence } \\
\text { Of } \\
\text { poverty } \\
(2004)\end{array}$} & \multirow{3}{*}{$\begin{array}{c}\text { Unemplo- } \\
\text { ment rate } \\
(\%) \\
(2005)\end{array}$} \\
\hline & & & \multicolumn{2}{|c|}{ Shift } & & \\
\hline & & $\begin{array}{l}\text { National } \\
\text { Share }\end{array}$ & Mix & Competitive & & \\
\hline Johor & 721 & 612 & 89 & 108 & 2.0 & 2.1 \\
\hline Kedah & 357 & 417 & -69 & -80 & 7.0 & 2.6 \\
\hline Kelantan & 149 & 309 & 22 & -37 & 10.6 & 3.1 \\
\hline Malaka & 121 & 157 & 74 & 156 & 1,8 & 2.0 \\
\hline N. Sembilan & 177 & 209 & 30 & -32 & 1.4 & 2.4 \\
\hline Pahang & 220 & 310 & 32 & -89 & 4.0 & 2.7 \\
\hline Perak & 222 & 693 & 132 & -471 & 4.9 & 3.0 \\
\hline Perlis & 27 & 61 & 4 & -34 & 6.3 & 1.9 \\
\hline P. Pinang & 425 & 361 & 237 & 65 & 0.3 & 1.6 \\
\hline Selangor & 1427 & 635 & 371 & 792 & 1.0 & 1.7 \\
\hline Terengganu & 127 & 207 & 25 & -80 & 15.4 & 3.0 \\
\hline Kuala Lumpur\# & 216 & 334 & 233 & -118 & 1.5 & 1.4 \\
\hline Sabah \# & 987 & 384 & -80 & 603 & 23.0 & 5.0 \\
\hline Sarawak\# & 368 & 433 & -196 & -64 & 7.5 & 3.4 \\
\hline \multicolumn{2}{|c|}{$\begin{array}{l}\text { Rank correlation coefficient } \\
\text { with MIX component }\end{array}$} & - & - & - & $-0.82 * *$ & $-0.71^{* * *}$ \\
\hline
\end{tabular}

(Source: Calculations are based on State/District Data Book - Mala)sia 1987 to 2005, published by the Department of Statistics Malaysia)

Note: **Significant at 0.01 level. \#Employment data covers 1990- 2004.

The table also shows that all the state economies have positive shares and mix components for the industry sector except Kuala Lumpur, Sabah and Sarawak, in which case, the mix component is negative. The competitive components of industries of Perak, Terengganu and Kuala Lumpur are negative, 
implying that regional industries in these states are composed of units which are less competitive than the national industries. The performances of service sector of all the state economies have been good except Kelantan, Melaka, Perak, and Kuala Lumpur, in which case the achievement of a positive mix shift component along with a negative competitive component is indicative of the fact that these economies lost out to that extent in competitive position vis-à-vis the rest of the country. The analysis from the table appears to indicate that the employment growth of the state economies have highly depended on two sectors - industry and service rather than on agriculture. Sector-wise calculation of shift-share by states of Malaysia is given in Table 4 .

\section{FEDERAL GOVERNMENT DEVELOPMENT EXPENDITURE AND PRIVATE SECTOR INVESTMENT}

Data on federal government development expenditure which accounts for $70 \%$ of total by the states of Malaysia during the period of 1976-2005 presented in Table 2 shows that Kuala Lumpur followed by Sarawak, Pahang, Terengganu, Negeri Sembilan and Perlis have received higher percentage share of development expenditure than their percentage share of population. The low percentage recipients of federal fund have been Selangor followed by Sabah, Perak, Pulau Pinang and Kelantan. Similarly, the percentage share of industrial investments during 1986-2005 have been high in Terengganu followed by Pulau Pinang, Melaka, Sarawak, Selangor, Negeri Sembilan and Kedah, whilst Sabah, Kuala Lumpur, Kelantan, Perak and Pahang have received low shares of the private industrial investment.

Both the allocation of the federal development fund and the private sector investment were favourable to some states and at the same they were disproportionate to some other states of Malaysia and this provides the partial reasons for regional disparities of development among the states of the country. 
Table 2: Federal Government Development Expenditure by States of Malaysia during 1976-2005

\begin{tabular}{|c|c|c|c|}
\hline State & Expenditure (RM bl.) & Percentage & $\begin{array}{c}\text { Population \% } \\
\text { ('05) }\end{array}$ \\
\hline Johor & 26.04 & 9.0 & 11.9 \\
\hline Melaka & 7.55 & 2.6 & 2.7 \\
\hline N.Sembilan & 11.91 & 4.1 & 3.6 \\
\hline Perak & 19.92 & 6.9 & 8.5 \\
\hline Selangor & 37.84 & 13.0 & 18.2 \\
\hline P.Pinang & 12.41 & 4.3 & 5.6 \\
\hline $\mathrm{KL}$ & 41.40 & 14.3 & 6.1 \\
\hline Kedah & 20.43 & 7.0 & 6.9 \\
\hline Kelantan & 13.48 & 4.6 & 5.6 \\
\hline Pahang & 20.91 & 7.2 & 5.4 \\
\hline Perlis & 4.787 & 1.6 & 0.9 \\
\hline Sabah & 30.12 & 10.4 & 12.0 \\
\hline Sarawak & 29.14 & 10.0 & 8.8 \\
\hline Terengganu & 14.39 & 5.0 & 3.8 \\
\hline MALAYSIA & 290.332 & 100.0 & 100.0 \\
\hline
\end{tabular}

(Source: $2^{\text {nd }}, 3^{\text {rd }}, 4^{\text {th }}, 5^{\text {ht }}, 6^{\text {th }}, 7^{\text {th }}, 8^{\text {th }}$, and $9^{\text {th }}$ Malaysia Plans)

Table 3: Approval of Manufacturing Projects by States of Malaysia during 1986-2005

\begin{tabular}{|l|c|c|c|c|c|c|c|}
\hline $\begin{array}{l}\text { State } \\
\therefore\end{array}$ & $\begin{array}{l}\text { Number } \\
\text { Johor }\end{array}$ & $\begin{array}{l}\text { Employm- } \\
\text { ent (000) }\end{array}$ & $\begin{array}{l}\text { Investment } \\
\text { (RM bI.) }\end{array}$ & \% & $\begin{array}{l}\text { Popun } \\
\text { \% ('05 }\end{array}$ \\
\hline Melaka & 3694 & 22.8 & 438.9 & 21.4 & 59.98 & 13.5 & 11.9 \\
\hline N.Sembilan & 634 & 3.9 & 89.9 & 4.3 & 28.59 & 6.4 & 2.7 \\
\hline Perak & 652 & 4.0 & 89.7 & 4.3 & 22 & 4.9 & 3.6 \\
\hline Selangor & 4606 & 6.2 & 132.8 & 6.4 & 25.57 & 5.7 & 8.5 \\
\hline P.Pinang & 2128 & 13.1 & 298.4 & 14.5 & 41.85 & 9.4 & 5.6 \\
\hline KL & 430 & 2.6 & 34.5 & 1.7 & 3.93 & 0.9 & 6.1 \\
\hline Kedah & 952 & 5.9 & 153.6 & 7.4 & 35.17 & 7.9 & 6.9 \\
\hline Kelantan & 135 & 0.8 & 19.7 & 1.0 & 2.2 & 0.5 & 5.6 \\
\hline Pahang & 349 & 2.1 & 60.6 & 2.9 & 20.89 & 4.7 & 5.4 \\
\hline Perlis & 75 & 0.5 & 9.2 & 0.4 & 3.94 & 0.9 & 0.9 \\
\hline Sabah & 631 & 3.9 & 94.8 & 4.6 & 17.03 & 3.8 & 12.0 \\
\hline Sarawak & 629 & 3.9 & 121 & 5.9 & 48.06 & 10.8 & 8.8 \\
\hline Terengganu & 232 & 1.4 & 62.9 & 3.0 & 46.44 & 10.5 & 3.8 \\
\hline MALAYSIA & 16217 & $\mathbf{1 0 0}$ & $\mathbf{2 0 6 3 . 5}$ & $\mathbf{1 0 0}$ & $\mathbf{4 4 4}$ & $\mathbf{1 0 0}$ & $\mathbf{1 0 0 . 0}$ \\
\hline
\end{tabular}

(Sources: $4^{\text {th }}, 5^{\text {th }}, 6^{\text {th }}, 7^{\text {th }}, 8^{\text {th }}$, and $9^{\text {th }}$ Malaysia Plans) 
Table 4: Shift-and-Share Analysis of Employment Types by States of Malaysia, 1982-2004 (in 000s).

\begin{tabular}{|c|c|c|c|c|c|c|c|c|c|c|c|c|c|c|c|c|}
\hline \multirow{2}{*}{$\begin{array}{l}\text { Sectors } \\
\text { /States }\end{array}$} & \multicolumn{4}{|c|}{ Agriculture } & \multicolumn{4}{|c|}{ Industry } & \multicolumn{4}{|c|}{ Service } & \multicolumn{4}{|c|}{ Total } \\
\hline & RG & SH & MIX & $\mathrm{COM}$ & RG & $\mathrm{SH}$ & MIX & $\mathrm{COM}$ & RG & $\mathrm{SH}$ & MIX & $\mathrm{COM}$ & $R G$ & SH & MIX & $\mathrm{COM}$ \\
\hline Jolror & -46 & 220 & -294 & -267 & 368 & 147 & 3 & 225 & 399 & 249 & 381 & 150 & 721 & 612 & 89 & 108 \\
\hline Kedah & -66 & 214 & -286 & .280 & 185 & 62 & 1 & 123 & 238 & 141 & 215 & 97 & 357 & 417 & -69 & -80 \\
\hline Kelantan & -61 & 126 & -168 & -187 & 112 & 60 & 1 & 52 & 98 & 124 & 189 & -25 & 149 & 309 & 22 & -37 \\
\hline Malaka & -10 & 37 & -49 & .46 & 55 & $4 !$ & 1 & 14 & 75 & 80 & 122 & -5 & 121 & 157 & 74 & 156 \\
\hline $\begin{array}{r}\mathrm{N} . \\
\text { Sembilan }\end{array}$ & -12 & 80 & -106 & -91 & 70 & $4 !$ & 1 & 29 & 119 & 89 & 130 & 30 & 177 & 209 & 30 & -32 \\
\hline Pahang & 19 & 128 & .171 & -109 & 50 & 50 & 1 & 0 & 152 & 132 & 201 & 20 & 220 & 310 & 32 & -89 \\
\hline Perak & -99 & 248 & .330 & -347 & 123 & 145 & 3 & -22 & 119 & 301 & 460 & -102 & 222 & 693 & 132 & -471 \\
\hline Perlis & -10 & 26 & -34 & -36 & 11 & 10 & 0 & 1 & 27 & 25 & 38 & 2 & 27 & 61 & 4 & -34 \\
\hline P. Pinang & -2 & 35 & .47 & -37 & 209 & 141 & 3 & 68 & 218 & 185 & 282 & 33 & 425 & 361 & 237 & 65 \\
\hline Selangor & -20 & 113 & -151 & -133 & 469 & 183 & 3 & 286 & 978 & 339 & 518 & 639 & 1427 & 635 & 371 & 792 \\
\hline $\begin{array}{r}\text { Terengga } \\
\mathrm{mu}\end{array}$ & -8 & 75 & -101 & -83 & 39 & 50 & 1 & -11 & 95 & 82 & 125 & 13 & 127 & 207 & 25 & -80 \\
\hline FT KL\# & 0 & 3 & -5 & -3 & 5 & 91 & -30 & -87 & 211 & 240 & 268 & -29 & 216 & 334 & 233 & -118 \\
\hline Sabah\# & 259 & 167 & -251 & 92 & 241 & 48 & -16 & 192 & 487 & 168 & 187 & 318 & 987 & 384 & .80 & 603 \\
\hline Sarawak\# & -33 & 229 & -344 & -262 & 142 & 55 & -18 & 88 & 259 & 149 & 166 & 110 & 368 & 433 & -196 & -64 \\
\hline
\end{tabular}

(Source: Calculations based on data from State/ District Data Bank (All States) of Malaysia-1987; State/ District Data Bank - Malaysia- 2005, published by the Department of Statistics Malaysia, (1987) \& (2005))

Notes: $R G=$ Regional Growth; $S H=$ National Share Component; $M I X=$ Mix (Shift) Componen; COM = Competitive (Shift) Component. \# Employment data covers between 1990-2004. 


\section{CONCLUSION}

This paper has examined the economic growth of the state economies as regional entities of Malaysia over a period of three and a half decades in the case of production and more than two decades in the case of employment, within the context of the structural changes of the national economy. In spite of implementing several regional development strategies and policies from second Malaysia Plan (1971-1975), the spatial matrix of national growth shows that the economic growth process has been uneven across the 14 states of Malaysia, giving rise to regional disparities in income and employment growth. Both federal government development expenditure and private investments in different states of Malaysia have not been proportionate to their shares of national population and this partially explains the reason for the growth of regional imbalances in the country despite that the national economy has undergone transformation.

The findings of the paper have the following policy implications:

- Federal government development expenditure should at least be equity based if it does not favour the lagging regions;

- Effective fiscal policies are necessary to encourage private investments in less developed states and at the same time discourage it in the more developed states;

- Regional economies should try to improve their industrial mix component for fast growing national industries;

- Regional economies should try to develop more specialized industries.

Recently, Malaysia has formulated a National Physical Plan with 36 policies which provide a spatial dimension to national economic policies by coordinating sectoral allocation of resources within the framework of regional, state and local planning. The first fifteen policies are directed towards reducing regional imbalances in the country. Among these, the most important ones are selective concentration in strategic urban centres for all states in P. Malaysia (NPP2, p.5-7), adoption of industrial clusters in selected urban conurbations and resource-based clusters and craft-based clusters in less developed states to serve as a catalyst for growth ((NPP5, p.5-10), developing a rational land use strategy to support the Third National Agricultural Policy (NAP3). Furthermore, it has been stated that land and natural resources of the less developed regions which still remain not fully utilised, should be further used to increase the productivity of those regions and therefore, help reduce regional imbalances. Resource-based industries, forestry-based activities and industries, downstream agriculturebased activities, resort tourism, in particular eco-tourism, craft-based industries 
and other niche activities - in other words, economic activities that are not subject to the same degree of competition as the activities that are being attracted to conurbations should be directed in the less developed regions" (JPBD-NPP, 2005, pp. 4-6). The NPP policies are supportive of the policy implications suggested in this paper. These policies when implemented effectively are expected to contribute towards ameliorating regional imbalances in Peninsular Malaysia, if not for the whole of Malaysia, because NNP is for P. Malaysia only.

\section{REFERENCES:}

Ariff, M., 1991. The Malaysian Economy: Pacific Connections. Singapore: Oxford University Press.

Aiken, S. R., Leigh C.H., Leinbach T. R. and Moss M. R., 1982. Development and Environment in Peninsular Malaysia. Singapore: McGraw-Hill International Book Co.

Armstrong, H. and Taylor J., 2004. Regional Economics and Policy. Oxford: Blackwell Publishing.

Armstrong, H. and Taylor J., 2002. European Union Regional Policy: Reconciling the Convergence and Evaluation Evidence, in J.R. Cuadrado-Roura and M. Parellada (eds.) Regional Convergence in the European Union. Advances in Spatial Science, Springer.

Armstrong, H.W., 1995. Convergence Among Regions of the EU, 195090. Papers in Regional Science, 74:143-151.

Athukorala, Prem-chandra, 2001. The Macroeconomy up to 1997, in Barlow, Colin (ed.), 2001. Modern Malaysia in the Global Economy - Political and Social Changes into the $21^{\text {st }}$ Century.

Cheltenham, UK: Edward Elgar Publishing Ltd, pp.13-27.

Barro, R.J. and Sala-i-Martin X., 1995. Economic Growth. Boston: MacGraw-Hill.

Barro, R.J. and Sala-i-Martin X., 1992. Convergence. Journal of Political Economy, 100:289-97.

Blair, J.P., 1991. Urban and Regional Economics. Boston, USA: Richard D. Irwin Inc.

Choguill, C.L., 1979. Regional development in the Third World: a search for an integrated theory. TRP 18. UK: University of Sheffield.

EPU (Economic Planning Unit) (2006). Ninth Malaysia Plan 2006-2010. Putrajaya: Prime Minister's Department. 
EPU (Economic Planning Unit), 2001. Eighth Malaysia Plan 2001-2005. Putrajaya: Prime Minister's Department.

EPU (Economic Planning Unit) (1996). Seventh Malaysia Plan 19962000. Kuala Lumpur: Prime Minister's Department.

EPU (Economic Planning Unit) (1991). Sixth Malaysia Plan 1991-1995. Kuala Lumpur: Prime Minister's Department.

EPU (Economic Planning Unit) (1986). Fifth Malaysia Plan 1986-1990. Kuala Lumpur: Prime Minister's Department.

EPU (Economic Planning Unit) (1981). Fourth Malaysia Plan 19811985. Kuala Lumpur: Prime Minister's Department.

EPU (Economic Planning Unit) (1976). Third Malaysia Plan 1976-1980. Kuala Lumpur: Prime Minister's Department.

EPU (Economic Planning Unit) (1971). Second Malaysia Plan 19711975. Kuala Lumpur: Prime Minister's Department.

Fisch, O., 1984. Regional income inequality and economic development.

Regional Science and Urban Economics, 14:89-111.

Ghaffar, F., 1987. Regional Inequalities and Development in Peninsular Malaysia. Malaysian Journal of Tropical Geography, Vol.16, pp.23-36.

Gezici, F. And G.D. Hewings, 2004. Regional Convergence and the Economic Performance of Peripheral Areas in Turkey, Review of Urban and Regional Development Studies, 16(2): pp. 113-132.

Gezici, F. And G.D. Hewings, 2002. Spatial Analysis of Regional Inequalities in Turkey, Discussion Paper 02-T-11, Regional Economics Applications Laboratory. Urbana: University of Illinois. Gilbert, A. and Goodman D.E., 1976. Regional income disparities and economic development: a critique, in A. Gilbert (ed.). Development Planning and Spatial Structure. London: John Wiley and Sons.

Hamzah Jusoh, 1992. The application of Williamson's hypothesis to regional development in Malaysia, in Mohd Yaakob $\mathrm{Hj}$ Johari (ed.). Regional Development in Malaysia: Issues and Challenges. Kota Kinabalu, Malaysia: Institute for Development Studies, pp.2153.

Hansen, N.M., 1981. Development from above: the centre-down development paradigm, in W.B.Stohr and D.F.R. Taylor (eds.). Development from Above or Below?. NY: John Wiley and Sons. Hirschman, A.O., 1958. The Strategy of Economic Development. New Haven: Yale Univ. Press. 
JPBD (2006). National Urbanization Policy. Kuala Lumpur: Federal Department of Town and Country Planning (JPBD).

JPBD (2005). National Physical Plan. Kuala Lumpur: Federal Department of Town and Country Planning (JPBD).

Kamal Salih, et. al.,2000. Malaysia's Long Range Economic Outlook 1991-2000. Kuala Lumpur: MIER.

Lall, S. And Yilmaz S., 2001. Regional economic Convergence: Do policy instruments make difference? Annals of Regional Science, 35:153-166.

Mohd Yusof Kasim, 1992. Regional development in Malaysia: a review of past and present policies, in Mohd Yaakob $\mathrm{Hj}$ Johari (ed.). Regional Development in Malaysia: Issues and Challenges. Kota Kinabalu, Malaysia: Institute for Development Studies, pp.55-92.

Mera, K., 1973. On the urban agglomeration and economic efficiency.

Economic Development and Cultural Change, 22:467-75.

Myrdal, G., 1957. Economic Theory and Under-developed Regions. London: Duckworth.

Nichols, V., 1969. Growth poles: an evaluation of their propulsive effect. Environment and Planning, 1: pp. 193-208.

Okposin, S.B., Abdul Halim Abdul Hamid \& Ong Hway Boon, 1999. The Changing Phases of Malaysian Economy. London: ASEAN Academic Press.

Onn, F. C., 1986. New Economic Dynamo - Structures and Investment Opportunities in the Malaysian Economy. Sydney, Australia: Allen $\&$ Unwin.

Sala-i-Martin, 1996. The classical approach to convergence analysis, Economic Journal, 106:1019-36.

Salleh, G., 2000. Urbanisation \& Regional Development in Malaysia. Kuala Lumpur: Utusan Publications \& Distributions Sdn Bhd.

Tan, C. E. and Mohamed Ariff, 2001. Structural Change in the Malaysian Manufacturing Industry, in Barlow, C.(ed.) Modern Malaysia in the Global Economy - Political and Social Changes into the $21^{\text {st }}$ Century. UK: Edward Elgar, pp.59-73.

Tabuchi, T., 1988. Interregional income differentials and migration: their relationships. Regional Studies, 22: pp. 1-10.

Terasi, M., 2000. Regional Convergence in Italy and Spain: A Comparative Perspective, in Shaw, David, P. Roberts \& J. Walsh (eds) (2000). Regional Planning and Development in Europe. Aldershot: Ashgate Publishing Ltd. 
Theil, H., 1967. Economics and Information Theory. Amsterdam: NorthHolland.

Walsh, J.A. \& O’Kelly, M.E., 1979. An Information Theoretic Approach to Measurement of Spatial Inequality. Economic and Social Development, 4: pp. 267-286.

Williamson, J.G., 1965. Regional Inequality and the Process of National Development: A Description of the Patterns, Economic Development \& Cultural Change, 13: pp. 3-84.

Athukorala (2001) has identified a few factors to the impressive economic performance of Malaysia (p.21).

ii If not otherwise mentioned, the terms 'region' and 'state' have been used interchangeably in this paper.

iii $\beta$ (Beta)-convergence occurs when poor regions grow faster than rich regions, implying a negative relationship between the growth of per capita income over several decades and the level of per capita at the start of the period (Armstrong and Taylor, 2004, p.82).

iv $\sigma$ (Sigma)-convergence occurs when the dispersion of per capita income between regions falls over time. It is a more conventional measure of regional inequality (Armstrong and Taylor, 2004, p.82).

v For elaborate discussion on these regional strategies and policies, see Mohd Yusof Kasem (1992), Hamzah Jusoh (1992) and Salleh (2000).

$\checkmark$ Real Per Capita GDP has been calculated at 1978 prices.

vii Salleh (2000) has calculated regional inequality for Peninsular Malaysia during 1960-1990 and derived a similar tend (p.54).

viii The exchange rate between US\$ and Ringgit Malaysia is, US\$ $1.0=$ RM 3.75 .

ix In the Fourth Malaysia Plan \& also Ninth Malaysia Plan, states of Malaysia were grouped into five regions - Northern, Eastern, Central, Southern and East Malaysia states of Sabah and Sarawak. (4MP, 1986, p.81; RMK9, 2006, pp.358).

$x$ Agriculture comprises of farming, fishery, forestry, mining and quarrying; Industry consists of manufacturing and construction; and service is composed of finance, insurance, commerce, transport, storage, communication, government, utility and other services. 